\title{
Coagulation-Flocculation and Air Stripping as a Pretreatment of Young Landfill Leachate
}

\author{
Tuba Yilmaz, Selami Apaydin and Ali Berktay*
}

Department of Environmental Engineering, Selcuk University, 42075, Konya-Turkey.

\begin{abstract}
Leachate from sanitary landfills is a strong wastewater in terms of organic matter and ammonia. Both biological and chemical processes can be used for organic matter but ammonia reduction by nitrification-denitrification often poses problems due to inhibition. In this study, leachate from solid waste landfill in Konya Municipal area was used and organic matter and color removal were examined by using different chemical matters (Alum, $\mathrm{FeCl}_{3}, \mathrm{FeSO}_{4}$ ) in the $\mathrm{pH}$ adjustment with lime, $\mathrm{NaOH}$ and $\mathrm{H}_{2} \mathrm{SO}_{4}$. For ammonium removal, air stripping and its removal efficiency were investigated. For organic matter removal, the highest efficiencies were achieved as $44 \%$ by using $9 \mathrm{~g} / \mathrm{L}$ alum at $\mathrm{pH} 11$ adjusted with lime and as $45 \%$ by using $15 \mathrm{~g} / \mathrm{L} \mathrm{FeCl}_{3}$ concentration at $\mathrm{pH} 3$. Color removal studies in coagulation experiments indicated that the highest color removal efficiencies could be obtained when $\mathrm{pH}$ was adjusted with lime. The lowest coagulant concentration $1 \mathrm{~g} / \mathrm{L}$ yielded the similar removal efficiencies as the concentration increased. In ammonium removal with air stripping, the optimum flow rate was $1 \mathrm{~L} / \mathrm{min}$ and the optimum aeration time was 8 hours.
\end{abstract}

Keywords: Solid waste, landfill leachate, pre-treatment, coagulation-flocculation, air stripping.

\section{INTRODUCTION}

The degradation of the organic fraction of the municipal solid waste in landfill in combination with the percolation of rainwater produces a liquid called leachate [1-3]. One of the main problems with the solid waste landfill sites is leachate depending on large amounts of organic matter, ammonianitrogen, heavy metals, clorinated organic and inorganic salts.

Leachate is classified as young and old according to the age of the landfill site. Young leachate is characterized by chemical oxygen demand (COD) concentration higher than 5 $\mathrm{g} / \mathrm{L}$ and by low nitrogen concentration $(<400 \mathrm{mg} / \mathrm{L}$ of $\mathrm{N})$. Old leachate is characterized by a high nitrogen concentration $(>400 \mathrm{mg} / \mathrm{L}$ of $\mathrm{N})$, high content of recalcitrant compounds and low biodegradable organic fraction $\left(\mathrm{BOD}_{5} /\right.$ $\mathrm{COD} \leq 0.1)[4,5]$.

Usually a combination of physical, chemical and biological methods are used for the treatment of landfill leachate since it is difficult to have efficient treatment by one of these methods alone $[6,7]$. Aerobic, anaerobic and anoxic processes are the biological methods for leachate treatment and are usually used in combination [8-10]. Air stripping and adsorption are major physical methods whereas coagulationflocculation, chemical oxidation are chemical treatment methods $[7,11,12]$.

In water and wastewater treatment, coagulation and flocculation are used for removing high concentration organic pollutants, heavy metals and some anions [13-15]. Alumunium and iron coagulants are effective for the removal of humic substances [16-19].

*Address correspondence to this author at the Department of Environmental Engineering, Selcuk University, 42075, Konya-Turkey; Tel: +90.332.223 20 93; Fax: +90.332.241 06; E-mail: aberktay@ selcuk.edu.tr
Coagulation-flocculation is a relatively simple technique that may be employed successfully for the treatment of older landfill leachate [17]. However, this method may result in only moderate removals of COD (or TOC) content, apart from presenting a number of drawbacks: excessive sludge may be produced, and in certain cases, when the conventional chemical coagulants are used, increased aluminium and iron concentrations may be encountered in the resulting effluent [12]. Coagulation-flocculation has thus been proposed mainly as a pretreatment method for young leachate or as a post-treatment technique for the partially stabilized leachate [20]. Aluminium sulphate (alum), ferrous sulphate, ferric chloride and ferric chlorosulphate are commonly used as coagulants. Iron salts seem more efficient than aluminium ones [17].

Removal of nitrogen from wastewater can be accomplished through a variety of physicochemical and biological processes. Biological nitrification and denitrification are considered to be the most practical methods of treating high nitrogen in leachate. But high concentrations of organic matter, eventhough have been removed in anaerobic stages at high efficiencies, may hinder high degree of nitrification. High concentration of ammonia, inhibitors such as heavy metals, sulfides etc. which are of common existance in leachate also decrease nitrification efficiency. In such cases, physico-chemical treatment processes are more suitable [21]. One of those processes is air stripping. Collivignarelli et al. [22] studied ammonia removal from landfill leachate having $2100 \mathrm{mg} / \mathrm{L}$ ammonia. Experiments were carried out at $70{ }^{\circ} \mathrm{C}$ and at $\mathrm{pH} 11$ and the removal efficiency was $90 \%$. Cheung et al. [23] studied ammonia removal for two different flow rates $(1 \mathrm{~L} / \mathrm{min}, 5 \mathrm{~L} / \mathrm{min})$. at $20{ }^{\circ} \mathrm{C}$ and at $\mathrm{pH} 11$. Results revealed that after 24 hour-aeration, $81 \%$ and $90 \%$ removal efficiencies could be obtained for flow rates of $1 \mathrm{~L} / \mathrm{min}$ and $5 \mathrm{~L} / \mathrm{min}$, respectively. 
Table 1. Characterization of Landfill Leachate

\begin{tabular}{|c|c|c|}
\hline \multirow{2}{*}{ Parameters } & \multicolumn{2}{|c|}{ Concentrations } \\
\hline & Rainy Season & Dry Season \\
\hline $\mathrm{COD}(\mathrm{mg} / \mathrm{L})$ & $7676-8320$ & $39580-55450$ \\
\hline $\mathrm{BOD}_{5}(\mathrm{mg} / \mathrm{L})$ & 4050 & 36625 \\
\hline $\mathrm{NH}_{4}-\mathrm{N}(\mathrm{mg} / \mathrm{L})$ & $896-1122$ & $828-952.5$ \\
\hline $\mathrm{PO}_{4}-\mathrm{P}(\mathrm{mg} / \mathrm{L})$ & $35.18-38.8$ & $9.52-11.5$ \\
\hline $\mathrm{SS}(\mathrm{mg} / \mathrm{L})$ & $1400-2690$ & $550-1500$ \\
\hline Color (Pt-Co) & $4280-5160$ & $2961-14340$ \\
\hline $\mathrm{Ph}$ & $7.00-7.62$ & $6.81-7.17$ \\
\hline $\mathrm{Pb}(\mathrm{mg} / \mathrm{L})$ & \multicolumn{2}{|c|}{0.204} \\
\hline $\mathrm{Cd}(\mathrm{mg} / \mathrm{L})$ & \multicolumn{2}{|c|}{0.118} \\
\hline $\mathrm{Zn}(\mathrm{mg} / \mathrm{L})$ & \multicolumn{2}{|c|}{0.177} \\
\hline $\mathrm{Ca}(\mathrm{mg} / \mathrm{L})$ & \multicolumn{2}{|c|}{139.5} \\
\hline $\mathrm{Mg}(\mathrm{mg} / \mathrm{L})$ & \multicolumn{2}{|c|}{698} \\
\hline $\mathrm{Fe}(\mathrm{mg} / \mathrm{L})$ & \multicolumn{2}{|c|}{7.27} \\
\hline $\mathrm{Ni}(\mathrm{mg} / \mathrm{L})$ & \multicolumn{2}{|c|}{0.385} \\
\hline $\mathrm{Cr}(\mathrm{mg} / \mathrm{L})$ & \multicolumn{2}{|c|}{0.661} \\
\hline $\mathrm{BOD}_{5} / \mathrm{COD}(\mathrm{mg} / \mathrm{L})$ & \multicolumn{2}{|c|}{$0.44-0.8$} \\
\hline
\end{tabular}

The aim of this study is to examine the efficiency of the coagulation-flocculation process as a pre-treatment for organic matter and color removal in young landfill leachate. To achieve this, Alum, $\mathrm{FeCl}_{3}, \mathrm{Fe}_{2}\left(\mathrm{SO}_{4}\right)$ were used as coagulants. All coagulants were applied both at leachate's own $\mathrm{pH}$ value and at different $\mathrm{pH}$ values according to the selected coagulant. Also air stripping was used for ammonium removal at various air flow rates. Optimum aeration time and air flow rate for ammonium removal were determined.

\section{MATERIAL AND METHODS}

\section{Landfill Leachate}

Leachate was collected from landfill site of Konya city (Turkey) which is located between $36.5-39.5^{\circ}$ north latitude and $31.5-34.5^{\circ}$ east longitude. It is the largest province of Turkey at the altitude of about $1030 \mathrm{~m}$. The population of the city is approximately 950000 . The study area is a semi-arid region and receives little annual rainfall. For instance, the annual average rainfall is about $324 \mathrm{~mm}$ and was measured as $283 \mathrm{~mm}$ in the year of 2006 . The average temperature of the area is about $1.2{ }^{\circ} \mathrm{C}$ in winter and $22{ }^{\circ} \mathrm{C}$ in summer months. Landfill occupies 24 ha area with an average height of $8 \mathrm{~m}$ in the total area of 350 ha at the present time. The amount of solid waste is about $800-850$ tons/day in summer and 950-1000 tons/day in winter months yielding the average leachate flow rates of about $100 \mathrm{~m}^{3} /$ day.

Leachate samples collected from the landfill site were filled in plastic container, transported to the laboratory and stored at $4{ }^{0} \mathrm{C}$. Before testing, samples were removed from the refrigerator and were placed for about 2 hours at room temperature for conditioning.

The main characteristics of the leachate are chemical oxygen demand in the range of $7676-55420 \mathrm{mg} / \mathrm{L}$, biological oxygen demand after 5 days of $4050-36625 \mathrm{mg} / \mathrm{L}$. The characterization of leachate is given in Table 1. It is observed that presenting a relatively high value of $\mathrm{COD}$ and $\mathrm{BOD}_{5}$ and the rate of $\mathrm{COD} / \mathrm{BOD}_{5}$ values indicates that the leachate can be defined as young. There has beeen low COD and $\mathrm{BOD}_{5}$ concentrations according to the samples taken between January and December in 2006 depending on the monthly rainfall. It is observed that the reason of low values in $\mathrm{COD}$ and $\mathrm{BOD}_{5}$ concentration is the dilution via rainfall. Changes of COD concentrations corresponding to the total amount of monthly rainfall in landfill site according to data from the meteorological services are given in Fig. (1).

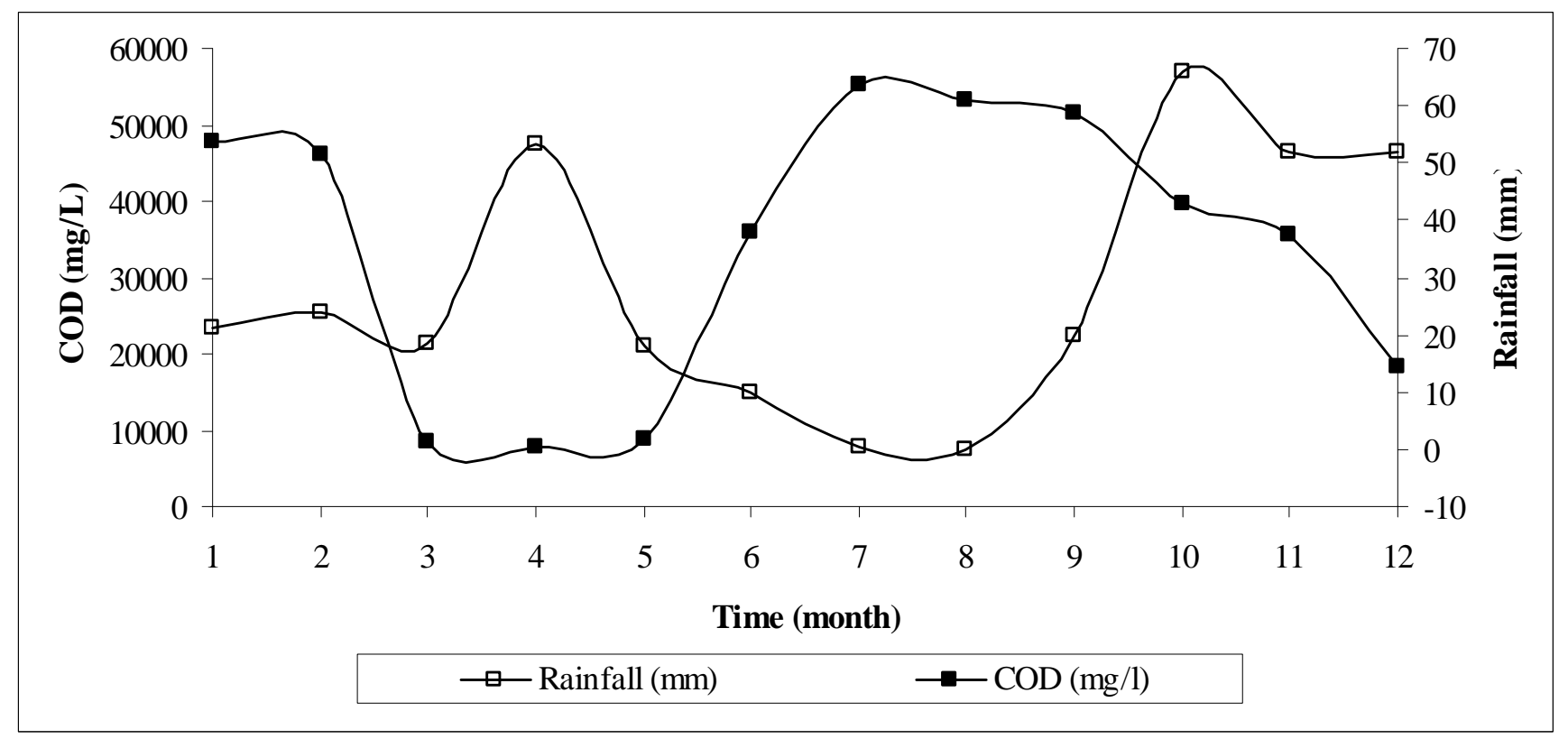

Fig. (1). Changes of COD concentrations corresponding to the total amount of monthly rainfall. 


\section{Experimental System}

Studies were carried out in two steps. The first one was coagulation-flocculation for organic matter and color removal and the other was air stripping for ammonium removal. Coagulation-flocculation and precipitation studies were performed in a conventional jar test apparatus equipped with 4 beakers of $250 \mathrm{~mL}$. The initial rapid mixing stage took place for 5 minutes at $126 \mathrm{rpm}$, following the slow mixing stage for 25 minute at $38 \mathrm{rpm}$ and settling for 1 hour. All experiments were both performed at leachate's own $\mathrm{pH}$ values and appropriate $\mathrm{pH}$ values for the coagulants. Adjustment of the leachate's $\mathrm{pH}$ to the desired values was provided by addition of adequate amounts of $\mathrm{Ca}(\mathrm{OH})_{2}, \mathrm{NaOH}$ and $\mathrm{H}_{2} \mathrm{SO}_{4}$. Alum, $\mathrm{FeCl}_{3}$ and $\mathrm{FeSO}_{4}$ were used as coagulants. After the settling period, the supernatant was withdrawn from the beaker and was used for analysis. In this study, $\mathrm{Ca}(\mathrm{OH})_{2}$ is used only for $\mathrm{pH}$ adjustment although it can be used as a coagulant. The use of lime as an alternative coagulant presented several drawbacks such as increase of hardness, low COD removal efficiency resulting to the production of excessive sludge quantities.

Air stripping studies consisted of beakers of $500 \mathrm{~mL}$. Aeration was provided by air pump via diffusers at three flow rates $(1 \mathrm{~L} / \mathrm{min}, 2 \mathrm{~L} / \mathrm{min}$ and $5 \mathrm{~L} / \mathrm{min})$ throughout 24 hours and the $\mathrm{pH}$ was adjusted to 11 by adding $\mathrm{Ca}(\mathrm{OH})_{2}$. Leachate was sampled after $0,2,4,6,8,12$ and 24 hours aeration time and analyzed for ammonia.

\section{Analytical Methods}

Leachate characterization studies were carried out between January and December in 2006 with two samples in a month. In the characterization studies, $\mathrm{BOD}_{5}, \mathrm{COD}, \mathrm{NH}_{4}-\mathrm{N}$, $\mathrm{PO}_{4}-\mathrm{P}, \mathrm{pH}$, temperature and heavy metals were analyzed. Temperature and $\mathrm{pH}$ were measured by using a WTW Multiparameter instrument's probe. COD was analyzed by the closed reflux titrimetric methods dictated by Standart Methods [24]. Standard kits (Dr.Lange) and spectrophotometric methods were used for $\mathrm{NH}_{4}-\mathrm{N}$ (Kit no: $\mathrm{LCK} 302$ ) and $\mathrm{PO}_{4}-\mathrm{P}$ (Kit no: LCK 350) analysis. Heavy metals were analyzed by ICP-EOS analyzer (Perkinelmer Optima, 2200DV). Color measurements were reported as true color (filtered by using $0.45 \mu \mathrm{m}$ filter paper) assayed at $455 \mathrm{~nm}$ using DR 2000 $\mathrm{HACH}$ spectrophotometer according to the method given by Standart Methods [24], Method no 2120C reported in platinium-cobalt (Pt-Co), the unit of color being produced by $1 \mathrm{mg}$ platinium/l in the form of the chloroplatinate ion. The performance of coagulation-flocculation was determined by the means of COD and color removal whereas air stripping was determined by means of $\mathrm{NH}_{4}-\mathrm{N}$ removal.

\section{RESULTS AND DISCUSSION}

\section{COD Removal}

The results of alum coagulation are presented in Fig. (2a). COD removal as a function of alum dosage is shown at different $\mathrm{pH}$ values (at $\mathrm{pH} 11$ and $\mathrm{pH}$ 5.5) adjusted with $\mathrm{Ca}(\mathrm{OH})_{2}, \mathrm{NaOH}$ and $\mathrm{H}_{2} \mathrm{SO}_{4}$. In $\mathrm{pH}$ adjustment to 11 with lime $\left(\mathrm{Ca}(\mathrm{OH})_{2}\right)$, the highest value of COD removal was $39 \%$ and was obtained using alum dosage of $7 \mathrm{~g} / \mathrm{L}$ whereas the highest value of COD removal is $44 \%$ at $9 \mathrm{~g} / \mathrm{L}$ alum dosage in $\mathrm{pH}$ adjustment to 11 with $\mathrm{NaOH}$. When $\mathrm{pH}$ was adjusted to 5.5 with $\mathrm{H}_{2} \mathrm{SO}_{4}$, COD removal efficiency was $42 \%$ and optimum alum dosage was $7 \mathrm{~g} / \mathrm{L}$.

In $\mathrm{FeCl}_{3}$ coagulation, $\mathrm{pH} 3$, pH 11 and leachate's own $\mathrm{pH}$ values were studied. The results of the effects for different dosages of $\mathrm{FeCl}_{3}$ as coagulant on the removal of COD from the landfill leachate were presented in Fig. (2b). The highest COD removal was $55 \%$ and was reached at $15 \mathrm{~g} / \mathrm{L} \mathrm{FeCl}_{3}$ dosage at $\mathrm{pH} 11$ adjusted with lime but system didn't reach the steady state condition. At leachate's own $\mathrm{pH}$ value, the highest COD removal was $33 \%$ which was the lowest value of the set and was reached at $15 \mathrm{~g} / \mathrm{L} \mathrm{FeCl}_{3}$ dosage. At $\mathrm{pH} 3$, COD removal was higher according to leachate's own $\mathrm{pH}$ and was $45 \%$. And at $\mathrm{pH} 11$ adjusted with $\mathrm{NaOH}$, COD removal was $36 \%$ at $11 \mathrm{~g} / \mathrm{L} \mathrm{FeCl}_{3}$ dosage. This result shows similarity with the study of Maranon et al. [28] that they found $\mathrm{pH} 3.8$ as the optimal $\mathrm{pH}$ for $\mathrm{FeCl}_{3}$ on the color, COD and turbidity removal.

In $\mathrm{FeSO}_{4}$ coagulation, $\mathrm{pH} 3$, pH 11 and leachate's initial $\mathrm{pH}$ values were studied. Results are presented in Fig. (2c). Of all the $\mathrm{pH}$ adjustment alternatives, the highest COD removal was obtained at $3 \mathrm{~g} / \mathrm{L} \mathrm{FeSO}_{4}$ dosage in $\mathrm{pH}$ adjustment with lime and the efficiency was $43 \%$. In $\mathrm{pH}$ adjustment with $\mathrm{NaOH}$, the highest $\mathrm{COD}$ removal was $32 \%$ at $7 \mathrm{~g} / \mathrm{L}$ $\mathrm{FeSO}_{4}$ dosage whereas the highest values of COD removal was $35 \%$ at $9 \mathrm{~g} / \mathrm{L} \mathrm{FeSO}_{4}$ dosage when $\mathrm{pH}$ was adjusted to 3 with $\mathrm{H}_{2} \mathrm{SO}_{4}$.

Coagulation-flocculation is more effective in old landfill leachate rather than in young landfill leachate, so number of studies was applied to old landfill leachate [15, 25-27], but studies for young landfill were limited leachate $[20,28]$. So when compared to the studies on old and young landfill leachate there are some distinction in COD removal efficiencies. Tatsi et al., [20] studied both young and old landfill leachate without and with $\mathrm{pH}$ adjustment and the results on young landfill leachate almost were similar to this study. The maxium COD removal efficiency for alum was $38 \%$ at the dosage of $3 \mathrm{~g} / \mathrm{L}$ at $\mathrm{pH} 10$ adjusted with lime. In this study the COD removal efficiency for alum was $33 \%$ at the dosage of $3 \mathrm{~g} / \mathrm{L}$ at $\mathrm{pH} 11$ and increased with coagulant concentration and was maxium at $7 \mathrm{~g} / \mathrm{L}$ alum $(39 \%)$.

\section{Color Removal}

In $\mathrm{pH}$ adjustment to 11 with lime and $\mathrm{NaOH}$, color removal efficiencies were $99 \%$ and $98 \%$ at $3 \mathrm{~g} / \mathrm{L}$ and $5 \mathrm{~g} / \mathrm{L}$ alum concentrations, respectively. No color removal was obtained in $\mathrm{pH}$ adjustment to 5.5. During coagulation it was realized that there was not any distinctive difference in removal efficiency at higher coagulant concentrations so the minimum coagulant concentration was capable of obtaining color removal as much as higher concentrations could do. The results are shown in Fig. (3a).

In leachate's own $\mathrm{pH}$ value, color removal was $88 \%$ at 15 $\mathrm{g} / \mathrm{L} \mathrm{FeCl}_{3}$ concentration wheras color removal was $63 \%$ at pH 3 adjusted with $\mathrm{H}_{2} \mathrm{SO}_{4}$. This value was the lowest color removal efficiency of the set. And at $\mathrm{pH} 11$ adjusted with $\mathrm{NaOH}$, color removal was $93 \%$ at $11 \mathrm{~g} / \mathrm{L} \mathrm{FeCl}{ }_{3}$ dosage. The highest color removal efficiency was achieved at $1 \mathrm{~g} / \mathrm{L} \mathrm{FeCl}{ }_{3}$ concentration at $\mathrm{pH} 11$ adjusted with lime and was $98 \%$. Color removals in $\mathrm{FeCl}_{3}$ coagulation are presented in Fig. (3b). 


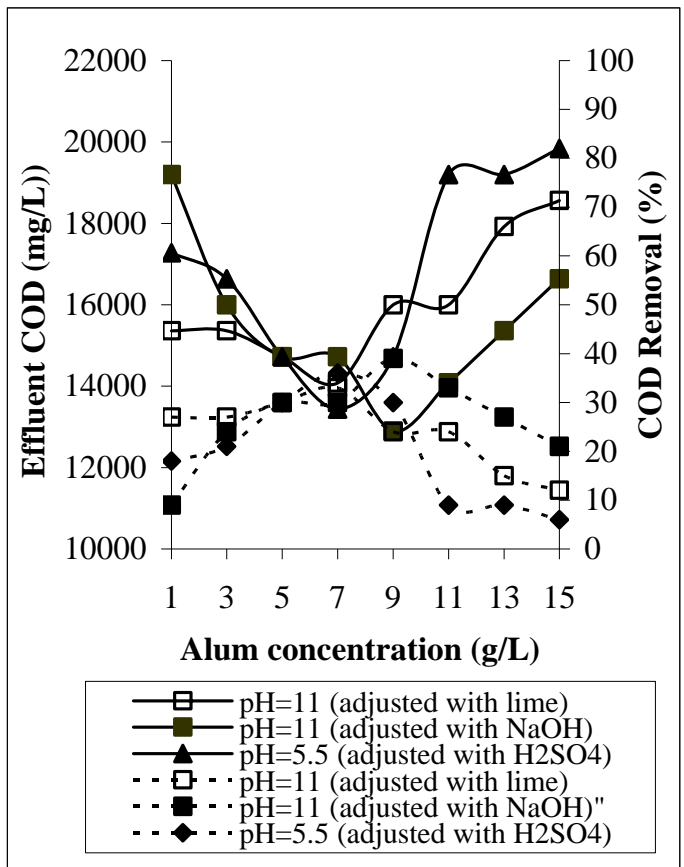

Figure 2a. Coagulation with Alum

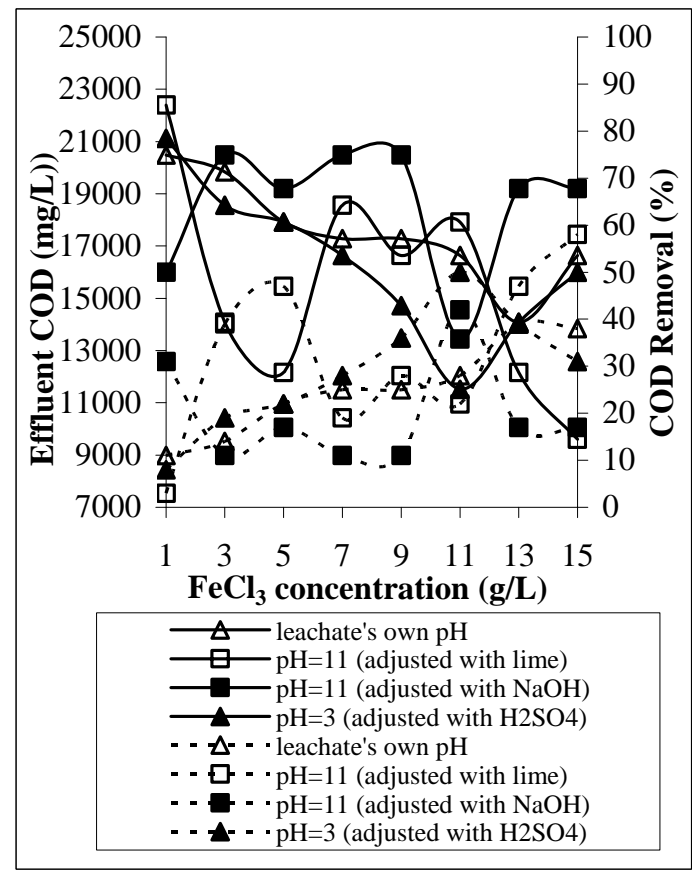

Figure 2b. Coagulation with $\mathrm{FeCl}_{3}$

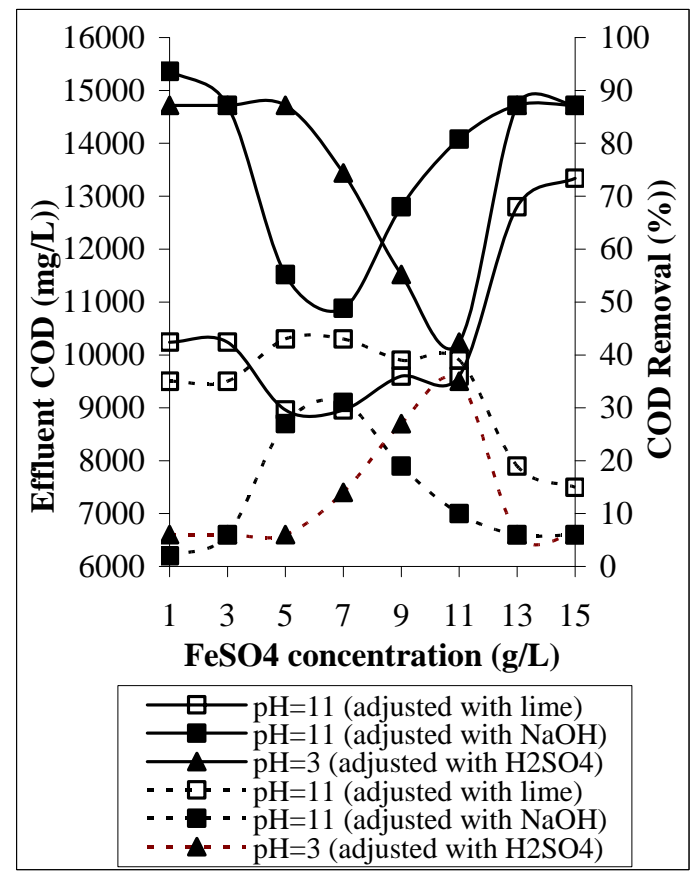

Figure 2c. Coagulation with $\mathrm{FeSO}_{4}$

Fig. (2). Effluent COD concentration and COD removal with chemical matters (data shown with straight line represent effluent COD whereas dash line represent COD removal).

In $\mathrm{FeSO}_{4}$ coagulation, the highest color removal was 99\% and was obtained at $1 \mathrm{~g} / \mathrm{L} \mathrm{FeSO}_{4}$ concentration in $\mathrm{pH}$ adjustment with lime. In adjustment with $\mathrm{NaOH}$, color removal efficiency was $87 \%$ whereas it was $67 \%$ in $\mathrm{pH}$ ad- justment to 3 with $\mathrm{H}_{2} \mathrm{SO}_{4}$, at $7 \mathrm{~g} / \mathrm{L}$ and $9 \mathrm{~g} / \mathrm{L} \mathrm{FeSO}_{4}$ dosages, respectively. Color removals in $\mathrm{FeSO}_{4}$ coagulation are presented in Fig. (3c). 


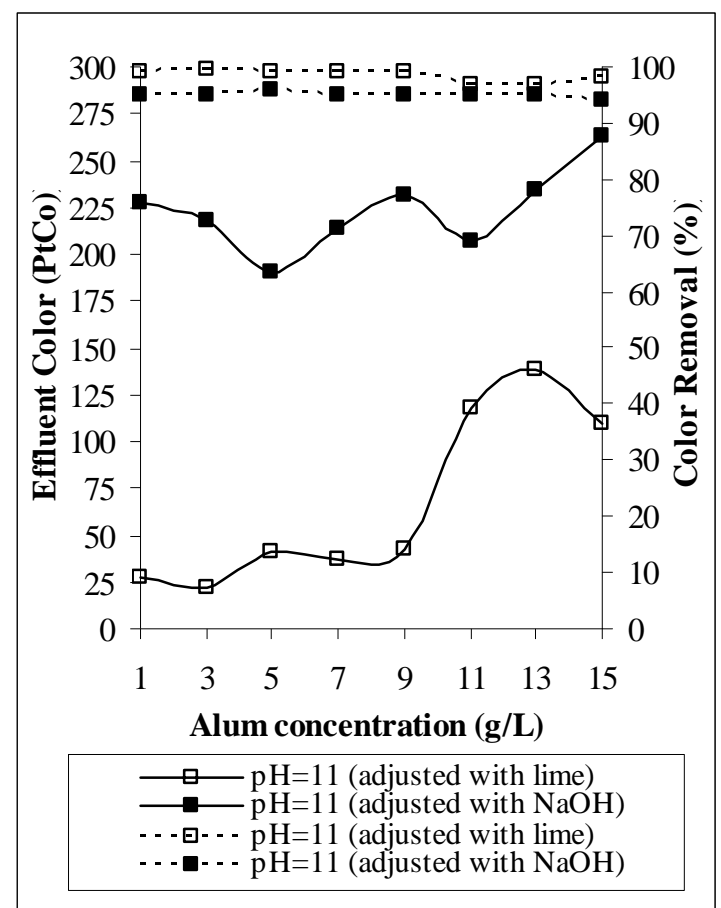

Figure 3a. Coagulation with alum

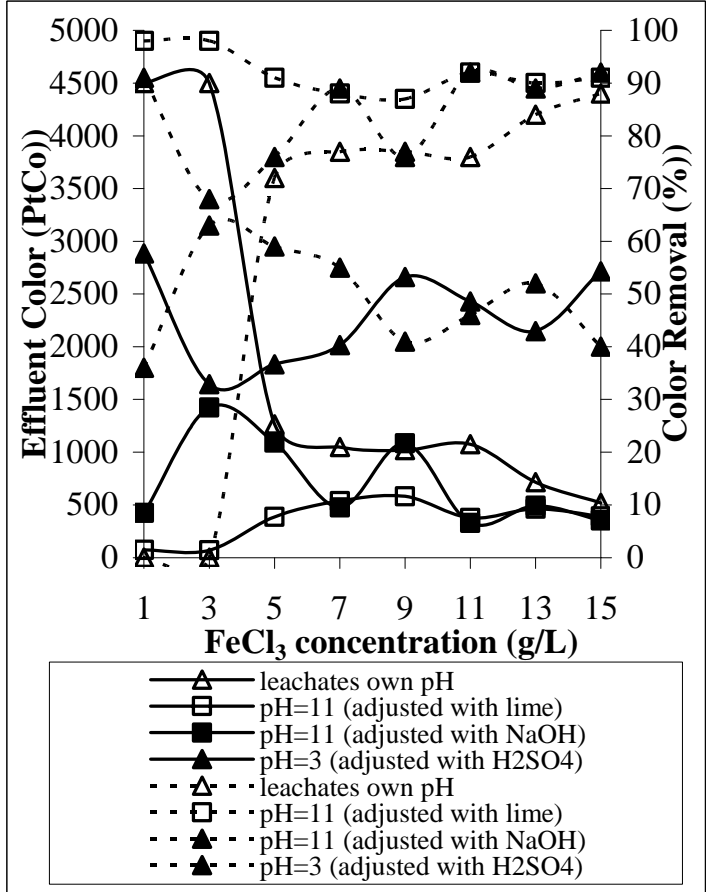

Figure 3b. Coagulation with $\mathrm{FeCl}_{3}$

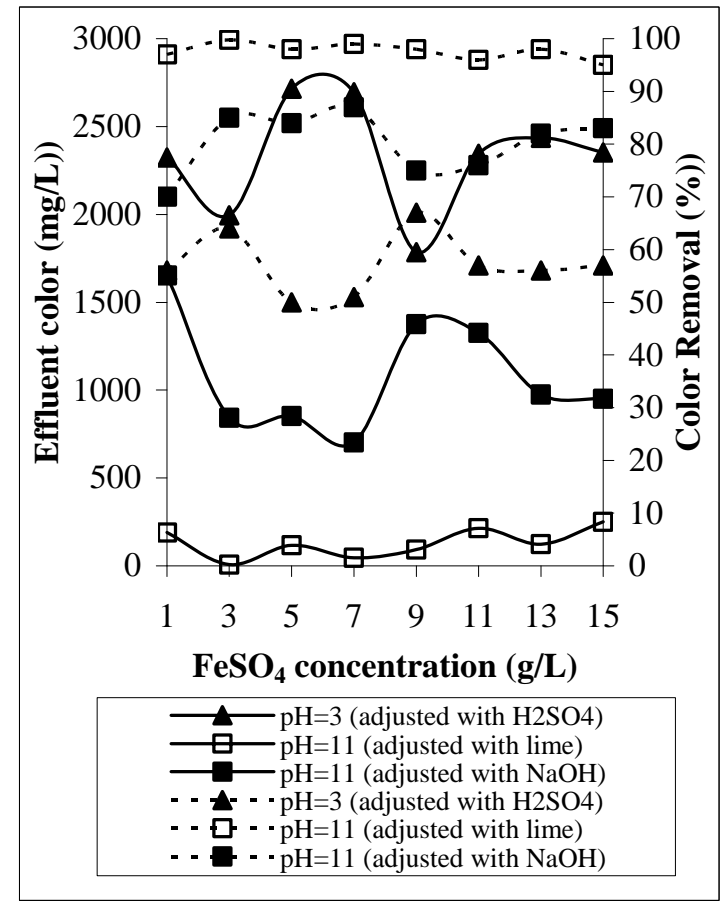

Figure 3c. Coagulation with $\mathrm{FeSO}_{4}$

Fig. (3). Effluent color and color removal with chemical matters (data shown with straight line represent effluent COD whereas dash line represent COD removal).

In this study, high color removal efficiencies were obtained with high coagulant dosages. Studies with young landfill leachate were performed with lower coagulant concentrations than this study. Maranon et al (2008) [28], studied $\mathrm{FeCl}_{3}$ and $\mathrm{Al}_{2}\left(\mathrm{SO}_{4}\right)_{3}$ at $0.4-0.8 \mathrm{~g} / \mathrm{L}$ coagulant concentra- tions and obtained $28.1 \%$ and $27 \%$ COD removal, respectively. Also they studied color removal and at these concentrations, removal efficiencies were $78.4 \%$ and $84.3 \%$. Similar to this study, highest color removal efficiency was achieved with alum coagulation. 


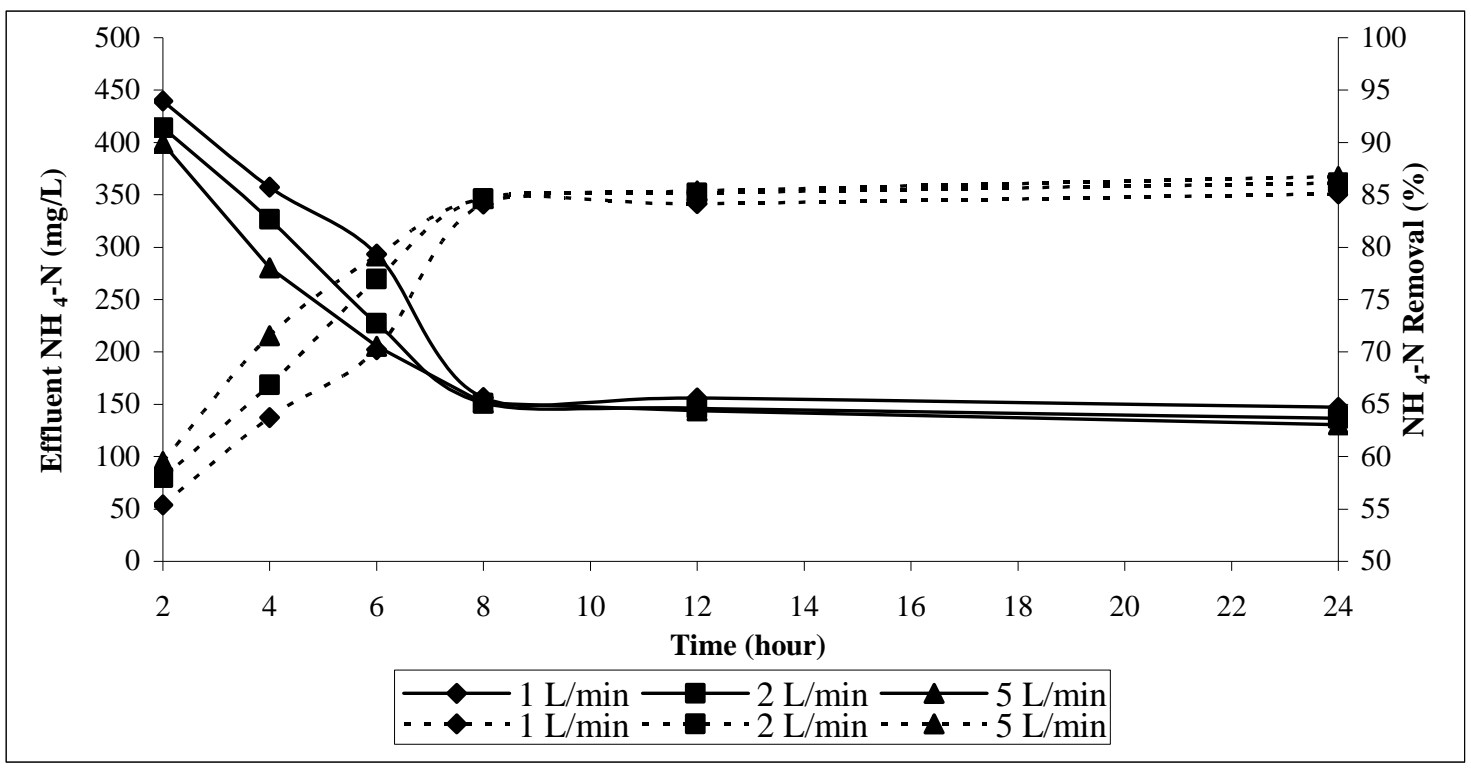

Fig. (4). Effluent ammonium concentrations at various flow rates and aeration times (data shown with straight line represent effluent $\mathrm{NH}_{4}-\mathrm{N}$ whereas dash line represent $\mathrm{NH}_{4}-\mathrm{N}$ removal).

\section{Air Stripping}

The effluent ammonium concentrations at various flow rates and aeration times are presented in Fig. (4). As it can be seen in the figure, the initial ammonium concentration was $985.5 \mathrm{mg} / \mathrm{L}$ at the beginning of the air stripping studies. After 2 hour-aeration, ammonium removal rates were $55 \%$, $58 \%$ and $60 \%$ at the flow rates of $1 \mathrm{~L} / \mathrm{min}, 2 \mathrm{~L} / \mathrm{min}$ and 5 $\mathrm{L} / \mathrm{min}$, respectively. With increasing aeration time, ammonium removal was also increased and after 24 hours aeration, the highest removal rates were obtained. The ammonium removal rates were $85 \%, 86 \%$ and $87 \%$ at the flow rates of 1 $\mathrm{L} / \mathrm{min}, 2 \mathrm{~L} / \mathrm{min}$ and $5 \mathrm{~L} / \mathrm{min}$, respectively. But after 8 hours aeration, the ammonium removal efficiencies were $84 \%$, $84 \%$ and $85 \%$ at the flow rates of $1 \mathrm{~L} / \mathrm{min}, 2 \mathrm{~L} / \mathrm{min}$ and 5 $\mathrm{L} / \mathrm{min}$, respectively. There were not many changes for the removal efficiencies after 8 hour-aeration and the increase in the removal efficiencies was not meaningful beyond that. For this reason and economical aspects, the optimum ammonium removal efficiencies were obtained at 8 hour-aeration and $1 \mathrm{~L} / \mathrm{min}$ flow rate. Similar results were seen in the study of Cheung et al. [23]. Their ammonium removal efficiency was increased proportional to increased air flow rate and aeration time and after 24 hour-aeration, $81 \%$ and $90 \%$ ammonia removals were achieved at flow rates of $1 \mathrm{~L} / \mathrm{min}$ and $5 \mathrm{~L} / \mathrm{min}$, respectively. In this study, higher removal efficiencies at $\mathrm{pH} 11$ were obtained when compared with the study of Ozturk et al. and Kabdasli et al. [21, 29].

\section{CONCLUSIONS}

The coagulation-flocculation experiments indicated that the highest COD removals were achieved at $9 \mathrm{~g} / \mathrm{L}$ alum and $5 \mathrm{~g} / \mathrm{L} \mathrm{FeSO}{ }_{4}$ concentrations at $\mathrm{pH} 11$ adjusted with the use of lime. The COD removal efficiencies were $44 \%$ and $43 \%$, respectively. In $\mathrm{FeCl}_{3}$ coagulation, 55\% COD removal efficiency at $\mathrm{pH} 11$ adjusted with lime was achieved but the system could not reach a steady state condition for the $\mathrm{FeCl}_{3}$ coagulation. In addition to this, it was seen that the optimum concentration was $11 \mathrm{~g} / \mathrm{L}$ at $\mathrm{pH} 3$ adjusted with $\mathrm{H}_{2} \mathrm{SO}_{4}$ and COD removal efficiency was $45 \%$.

Color removal studies in coagulation experiments indicated that the highest color removal efficiencies could be reached when $\mathrm{pH}$ was adjusted with lime. The similar removal efficiencies were obtained with the lowest coagulant concentration, $1 \mathrm{~g} / \mathrm{L}$, as the concentration increased. So it is determined that the optimum concentration in coagulation with alum, $\mathrm{FeSO}_{4}$ and $\mathrm{FeCl}_{3}$ was $1 \mathrm{~g} / \mathrm{L}$. In air stripping studies, the optimum flow rate was $1 \mathrm{~L} / \mathrm{min}$ and the optimum aeration time was 8 hours. With increasing flow rates and aeration times, there was not any considerable increase in $\mathrm{NH}_{4}-\mathrm{N}$ removal.

As a result of this study, it is determined that high chemical concentrations were required when coagulationflocculation method was used as a pre-treatment method. It can be concluded that this method could be used as a post treatment method for young landfill leachate. Therefore, this provides both low chemical use and low sludge production.

\section{ACKNOWLEDGEMENTS}

This research was supported by the Scientific Research Projects Department of Selcuk University, with the Project no 08401037 , Konya, Turkey.

\section{REFERENCES}

[1] H.J. Ehrig, "Quality and quantity of sanitary landfill leachate", Water Manag. Res., vol., 1, pp.53-68, 1983.

[2] B.Clement, "Physico-chemical Character ization of 25 French Landfill Leachates", in: Proceedings of the Sardinia 95, Fifth International Landfill Symposium", Cagliari, Italy, 1995, pp. 315325.

[3] H. Fan, H. Shu, H. Yang, W. Chen, Characteristics of Landfill leachates in Central Taiwan. Sci. Total Environ., vol. 361, pp. 2537, 2006

[4] E. Diamondapoulos, "Characterization and treatment of recirculation-stabilized leachate". Water Res., vol. 28, pp. 2439-2445, 1994. 
[5] R.M. Ramirez Zamora, A. Duran Moreno, M.T. Orta de Velasquez, I. Monje Ramirez, "Treatment of landfill leachates by comparing advanced oxidation and coagulation". Water Sci. Technol., vol. 41, pp. 231-235, 2000.

[6] L. Chiang, J. Chang, C. Chung, "Electrochemical oxidation combined with physical-chemical pretreatment processes fort he treatment of refractory landfill leachate". Environ. Eng. Sci., vol. 18, pp. 369-378, 2001.

[7] D.H. Ahn, C. Yun-Chul, C. Won-Seok, "Use of coagulant and zeolite to enhance the biological treatment efficiency of high ammonia leachate". J. Environ. Sci. Health, vol. 37, pp. 163-173, 2002.

[8] E. Neczaj, E.Okoniewska, M. Kacprzak, "Treatment of landfill leachate by sequencing batch reactor". Desalination, vol. 185, pp. 357-362, 2005.

[9] E. Castillo, M. Vergara, Y. Moreno, "Landfill leachate treatment using a rotating biological contactor and an upward-flow anaerobic sludge bed reactor. Waste Manage" vol. 27, pp. 720-726, 2007.

[10] O.N. Agdag, D.T. Sponza, "Anaerobic/aerobic treatment of municipal landfill leachate in sequential two-stage up-flow anaerobic sludge blanket reactor (UASB)/completely stirred tank reactor (CSTR) systems". Process Biochem, vol. 40, pp. 895-902, 2005.

[11] S.K. Marttinen, R.H. Kettunen, K.M. Sormunen, R.M. Soimasuo, J. A. ve Rintala," Screening of physical-chemical methods for removal of organic material, nitrogen and toxicity from low strength landfill leachates", Chemosphere, vol. 46, pp. 851-858, 2002.

[12] D. Trebouet, J.P. Schlumpf, P. Jaounen, F. Quemeneur, "Stabilized landfill treatment by combined physicochemical-nanofiltration processes". Water Res., vol. 35, pp. 2935-2942, 2001.

[13] F. Kreith, Handbook of Solid Waste Management, McGraw Hill: New York, USA. 1994.

[14] H.A.M. Muhammad, N.S. Abuzaid, H.A.M. Aarif, "Coagulation of polymeric wastewater discharged by a chemical factory". Water Res., vol. 33, pp. 521-529, 1998.

[15] Z. Wang, Z. Zhang, Y. Lin, N. Deng, T. Tao, K, Zhuo, "Landfill leachate treatment by a coagulation-photooxidation process". $J$ Hazard Mater, vol. 95, pp. 153-159, 2002.

[16] H.W. Ching, M. Elimelech, J.G. Hering, "Dynamics of coagulation of clay particles with aluminum sulphate". J. Environ. Eng., vol. 120, pp. 169-189, 1994.

[17] A. Amokrane, C. Comel, J. Veron, "Landfill leachates pretreatment by coagulation-flocculation”. Water Res., vol. 31, pp. 2775-2782, 1997.
[18] M.C. Koether, J.E. Deutshman, G.W. VanLoon, "Low-cost polymeric aluminum coagulant". J. Environ. Eng., vol. 123, pp. 859-864, 1997.

[19] X. Lu, Z. Chen, X. Yang, "Spectroscopic study of aluminum speciation in removing humic substances by Al coagulation". Water Res., vol. 33, pp. 3271-3280, 1999.

[20] A.A. Tatsi, A.I. Zouboulis, K.A. Matis, P. Samaras, Coagulationflocculation pretreatment of sanitary landfill leachate. Chemosphere, vol. 53, pp. 737-744, 2003.

[21] I., Kabdasli, O.Tunay, I.Ozturk, S.Yılmaz, O. Arıkan, "Ammonia removal from young landfill leachate by magnesium ammonium phosphate precipitation and air stripping"., Water Sci. Technol., vol. 41, pp. 237-240, 2000.

[22] C. Collivignarelli, G. Bertanza, M. Baldi, F. Avezzu, "Ammonnia stripping from MSW landfill leachate in bubble reactors: Process Modeling and Optimization" Waste Res., vol. 16, pp. 455-466, 1998.

[23] K.C. Cheung, L.M. Chu, H. Wong, "Ammonia stripping as a pretreatment for landfill leachate". Water, Air Soil Pollut., vol. 94, pp. 209-221, 1997.

[24] APHA (American Public Health Association), Standard Methods for Examination of Water and Wastewater, $17^{\mathrm{th}}$ ed., Washington, DC, USA, 1998.

[25] F.J. Rivas, F. Beltran, F.Carvalho, B. Acedo, O. Gimeno, "Stabilized leachates: sequential coagulation-flocculation+chemical oxidation process". J. Hazard. Mater., vol. 116, pp. 95-102, 2004.

[26] X. Ntampou, A.I. Zouboulis, P. Samaras, "Appropriate combination of physico-chemical methods (coagulation/flocculation and ozonation) for the efficient treatment of landfill leachates". Che mosphere, vol. 62, pp. 722-730, 2006.

[27] A.H. Aziz, S. Alias, M.N. Adlan, Faridah, A.H. Asaari, M.S. Zahari, "Colour removal from landfill leachate by coagulation and flocculation processes". Bioresou Technol., Vol. 98, pp. 218-220, 2007.

[28] E. Maranon, L. Castrillon, Y. Fernandez-Nava, A. FernandezMendez, A. Fernandez-Sanchez, "Coagulation-flocculation as a pretreatment process at a landfill leachate nitrificationdenitrification plant", J. Hazard Mater., vol. 156, pp. 538-544, 2008.

[29] I. Ozturk, M. Altinbas, I. Koyuncu, O. Arikan, C. "Gomec-Yangin, advanced physico-chemical treatment experiences on young municipal landfill leachate", Waste Manage, vol. 23, pp. 441-446, 2003.

(C) Yilmaz et al.; Licensee Bentham Open.

This is an open access article licensed under the terms of the Creative Commons Attribution Non-Commercial License (http://creativecommons.org/licenses/by-nc/3.0/g) which permits unrestricted, non-commercial use, distribution and reproduction in any medium, provided the work is properly cited 